\title{
Effects of Limestone and Coal Bottom Ash on Setting Time of Blended Portland Cement (Ternary Cement)
}

\author{
Winner Matahula ${ }^{1 *}$ and Olumide Olubajo ${ }^{2}$ \\ ${ }^{1}$ University of Benin, Benin City, Nigeria \\ ${ }^{2}$ Abubakar Tafawa Balewa University, Nigeria
}

\begin{abstract}
In this study, the effects of coal bottom ash and limestone powder as supplementary cementing materials on the setting time of cement are investigated through Vicat penetration test in accordance with I.S.4031. These materials were used as substitutes for Portland cement in different proportions, and the setting behaviour of ternary blends were determined. Results showed that both initial and final setting time of ternary blends decreased with increase in limestone content, although at low replacement level (5-10\%), the opposite was the case. An emphatic delay seems to be caused by the addition of bottom ash (10-35\%). Both initial and final setting times increased in a somewhat proportional manner with increasing bottom ash content in all cases. At $35-40 \%$ total replacement with limestone, the final setting time increased significantly, due to dilution in the blended cement. The results obtained were compared to the international standard (IS: 8112), and it was found that the initial and final setting times were in the required ranges. Bottom ash is reactive, but far less than OPC and limestone.
\end{abstract}

Keywords: Ternary Cement; Portland Cement; Setting Time; Limestone; Coal Bottom Ash

\section{Introduction}

Portland cement which serves as the most commonly used cement today, is a closely controlled chemical combination of calcium, silicon, aluminium, iron and small amounts of other compounds, to which gypsum is added in the final grinding process to regulate the setting time of the concrete [1]. Setting is the term used to describe the stiffening of the cement paste. Setting is used to also describe the change of the cement paste from a fluid to a rigid state. Although, during setting, the paste acquires some strength, for practical purposes it's is important to distinguish setting from hardening. Hardening refers to the gain of strength of a set cement paste. Since the flash setting of $\mathrm{C}_{3} \mathrm{~A}$ is prevented by addition gypsum, $\mathrm{C}_{3} \mathrm{~S}$ sets first [2].

Concrete is the most commonly used building material throughout the world. It is a mixture of different ingredients such as cement, coarse aggregate, fine aggregate and water [3]. The individual properties of each ingredient have substantial influence on the properties of concrete. Out of these ingredients, cement acts as a bonding material for other ingredients [4].

A ternary mixture is simply a mixture of three components. Ternary cements are therefore three-component cements that are made by blending Portland cement (clinker + gypsum) with two supplementary cementing materials [5], such as coal fly ash, reactive bottom ash, natural pozzolans, granulated blast-furnace slag, silica fume and reactive rice-husk ash [6]. Ternary mixtures are uniquely suited to address the sustainability and cost aspect of Portland cement concrete [7]. Blending Portland cement with Supplementary additives has great influence on properties including setting time [7].

Supplementary cementing materials (SCMs) represent a broad class of predominately glassy materials that have been found to provide beneficial properties to Portland cement concrete. These materials may be inter-ground with cement clinker to create blended cement or they may be added directly to the concrete mixer during the batching process [8]. Supplementary cementitious materials are finely divided materials that fall into four types: those that are (a) cementitious, (b) pozzolanic, (c) both cementitious and pozzolanic, and (d) those that are nominally inert chemically. They include natural materials, processed natural materials, and artificial materials. They are finely divided and therefore form pastes to supplement Portland cement paste, in contrast to soluble admixtures that act as chemical accelerants or retardants during the hydration of Portland cement or otherwise modify the properties of the mixture (Figure 1).

Portland cement is the world's most versatile and utilized cement [8]. Because global demand for sustainability of Portland cement concrete (PCC) has risen, there is need to look for alternative additives and other SCMs to improve PCC workability and durability while lowering cement manufacturing cost [9]. Coal ash is known to be a

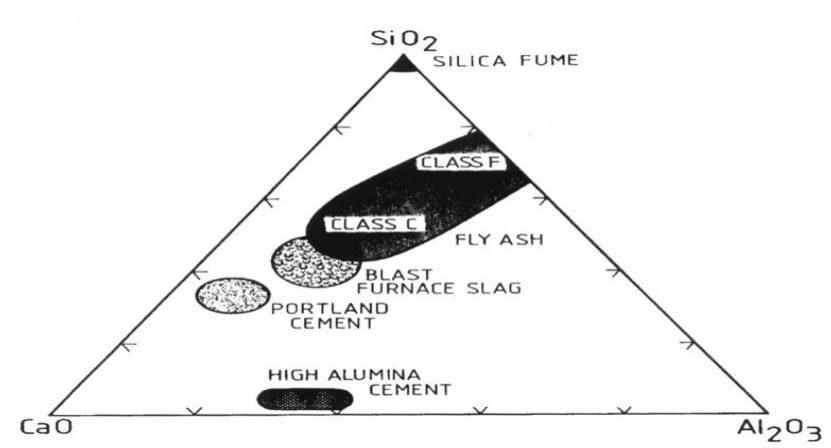

Figure 1: Bulk chemical composition ranges for some common supplementary cementitious materials (Source: Schlorholtz [8]).

*Corresponding author: Winner Matahula, University of Benin, Benin City, Nigeria, Tel: +2348188098214; E-mail: winmatbox@gmail.com

Received June 28, 2018; Accepted September 04, 2018; Published September 14,2018

Citation: Matahula W, Olubajo O (2018) Effects of Limestone and Coal Bottom Ash on Setting Time of Blended Portland Cement (Ternary Cement). J Material Sci Eng 7: 484. doi: 10.4172/2169-0022.1000484

Copyright: (c) 2018 Matahula W, et al. This is an open-access article distributed under the terms of the Creative Commons Attribution License, which permits unrestricted use, distribution, and reproduction in any medium, provided the original author and source are credited. 
good pozzolanic material for use in concrete. This work therefore looks at the prospects of using limestone and coal bottom ash as SCMs in ternary cement, by exploring their individual effects on the setting behaviour of cement.

\section{Experimental Details}

\section{Materials and methods}

Limestone was sourced from Ashaka Cement Company in Gombe State of Nigeria. The limestone was later crushed in a crusher and the resulting powder was sieved using a $150 \mu \mathrm{m}$ sieve. Coal bottom ash was obtained by burning of coal mined at Enugu, Nigeria. The coal was heated in a kiln to a temperature of about $900^{\circ} \mathrm{C}$. The resulting bottom ash was further crushed and sieved also using a $150 \mu \mathrm{m}$ sieve. Ashaka Cement (OPC) was also obtained from local distributors in Bauchi, Nigeria.

Limestone and coal bottom ash of equal fineness value $(150 \mu \mathrm{m})$ were prepared and the Physical and chemical analysis were carried out. OPC, and the pulverized coal bottom ash and limestone were analyzed using X-ray fluorescence spectrometry at Ashaka Cement Company in Gombe State of Nigeria. Cement pastes of different component ratios were prepared, as tests for initial and final setting times were carried out on the blended samples.

\section{Mix design}

Various mixes measuring $400 \mathrm{~g}$ each were prepared by blending the materials (SCMs) in different proportions. Limestone content was varied as bottom ash was fixed at $5 \%, 10 \%$ and $15 \%$. In the same vein, bottom ash content was varied at $5 \%$ limestone, $10 \%$ limestone and $15 \%$ limestone (Table 1). Tests for setting time were carried out on twenty nine different samples or blends. All tests were carried out at room temperature (Figure 2).

The amount of water required to give paste of standard consistency is obtained using the formula:Water required (in $\mathrm{ml})=0.85 \times \mathrm{P} \times \mathrm{W}$

Where $\mathrm{P}=$ Water of standard consistency (in \%)

$\mathrm{W}=\mathrm{Weight}$ of sample or mix (in grams).

\section{Preparation of test block}

- $400 \mathrm{~g}$ of sample (mix) was weighed and Poured into a mixing bowl.

- A neat sample paste was prepared by gauging the sample with water required to give a paste of standard consistency, and thoroughly mixed for three minutes.

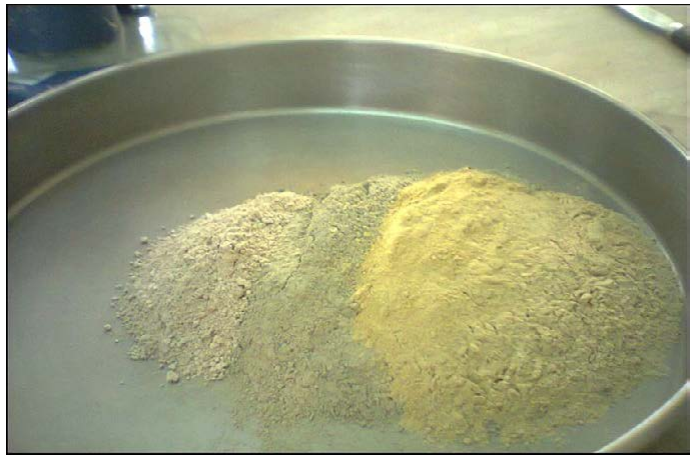

Figure 2: A sample containing limestone, coal ash and OPC (before blending)

\begin{tabular}{|c|c|c|c|c|c|}
\hline Sample & $\begin{array}{l}\text { OPC } \\
(\%)\end{array}$ & $\begin{array}{c}\text { Limestone } \\
(\%)\end{array}$ & $\begin{array}{l}\text { Coal bottom } \\
\text { ash (\%) }\end{array}$ & $\begin{array}{c}\text { Water of consistency } \\
(\%)\end{array}$ & $\begin{array}{l}\text { Water added } \\
(\mathrm{ml})\end{array}$ \\
\hline 1 & 90 & 5 & 5 & 33.5 & 113.9 \\
\hline 2 & 85 & 10 & 5 & 34.5 & 117.3 \\
\hline 3 & 80 & 15 & 5 & 35.5 & 120.7 \\
\hline 4 & 75 & 20 & 5 & 35.0 & 119.0 \\
\hline 5 & 70 & 25 & 5 & 34.4 & 117.0 \\
\hline 6 & 65 & 30 & 5 & 34.4 & 117.0 \\
\hline 7 & 60 & 35 & 5 & 34.2 & 116.3 \\
\hline 8 & 80 & 10 & 10 & 42.2 & 143.5 \\
\hline 9 & 75 & 15 & 10 & 43.0 & 146.2 \\
\hline 10 & 70 & 20 & 10 & 44.4 & 151.0 \\
\hline 11 & 65 & 25 & 10 & 42.0 & 142.8 \\
\hline 12 & 60 & 30 & 10 & 39.6 & 134.6 \\
\hline 13 & 70 & 15 & 15 & 44.5 & 151.3 \\
\hline 14 & 65 & 20 & 15 & 44.9 & 152.7 \\
\hline 15 & 60 & 25 & 15 & 45.3 & 154.0 \\
\hline 16 & 85 & 5 & 10 & 41.8 & 142.1 \\
\hline 17 & 80 & 5 & 15 & 44.0 & 149.6 \\
\hline 18 & 75 & 5 & 20 & 46.2 & 157.1 \\
\hline 19 & 70 & 5 & 25 & 48.3 & 164.2 \\
\hline 20 & 65 & 5 & 30 & 50.2 & 171.7 \\
\hline 21 & 60 & 5 & 35 & 52.6 & 178.7 \\
\hline 22 & 75 & 10 & 15 & 43.0 & 146.2 \\
\hline 23 & 70 & 10 & 20 & 47.2 & 160.5 \\
\hline 24 & 65 & 10 & 25 & 50.7 & 172.4 \\
\hline 25 & 60 & 10 & 30 & 53.4 & 181.6 \\
\hline 26 & 65 & 15 & 20 & 45.0 & 153.0 \\
\hline 27 & 60 & 15 & 25 & 46.5 & 158.1 \\
\hline 28 & 60 & 20 & 20 & 45.5 & 154.7 \\
\hline 29 & 100 & - & - & 32.0 & 108.8 \\
\hline
\end{tabular}

Table 1: Mix design and water requirement

- The time at which water was added to the sample was recorded.

- After mixing, the Vicat mould was immediately filled completely with the sample paste and the paste surface was ensured to be levelled with the top of the mould by the use of a hand trowel.

- The paste-filled mould was then placed under the Vicat apparatus.

\section{Test for initial setting time}

- The Vicat needle was lowered gently to make contact with the surface of the cement paste, after which the needle was quickly released in order to allow it penetrate the test block.

- The procedure was repeated after every 2 to 5 minutes until when needle failed to pierce the test block (paste in the mould) to a point $33 \mathrm{~mm}$ to $35 \mathrm{~mm}$ measured from top of the mould.

- The time at which the needle failed to pierce the test block to a point $33 \mathrm{~mm}$ to $35 \mathrm{~mm}$ measured from top of the mould was recorded.

- The time period elapsing between the time, water was added to the sample and the time, when the needle failed to pierce the test block by $33 \mathrm{~mm}$ to $35 \mathrm{~mm}$ measured from top of the mould was the initial setting time (Figure 3 ).

\section{Test for final setting time}

- The needle used for initial setting time was replaced by the one with an annular attachment. 


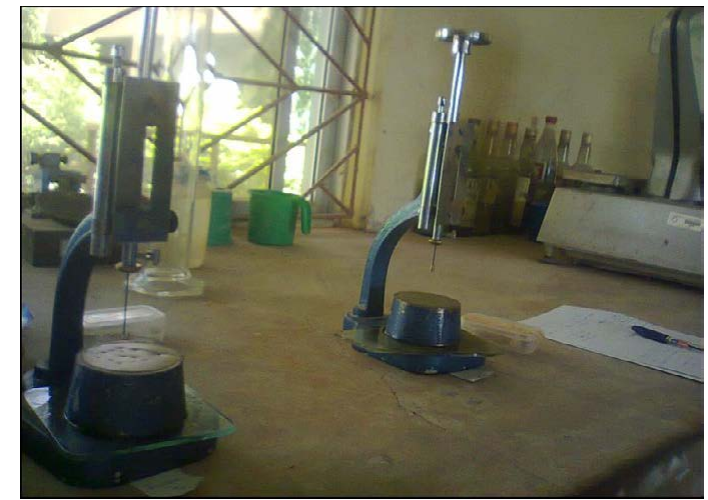

Figure 3: Experimental setup for Initial setting time test with Vicat needle (A) and final setting time test with Vicat needle + annular attachment $(B)$.

\begin{tabular}{|c|c|c|c|}
\hline Component & Limestone & $\begin{array}{c}\text { Coal Bottom } \\
\text { Ash }\end{array}$ & OPC \\
\hline Specific Gravity & 2.64 & 2.21 & 3.02 \\
\hline Density $\left(\mathrm{kg} / \mathrm{m}^{3}\right)$ & 2,083 & 1,389 & 2,703 \\
\hline $\begin{array}{c}\text { Specific surface area } \\
\left.\left(\mathrm{cm}^{2} / \mathrm{g}\right)\right)\end{array}$ & 4,890 & 3,553 & 3,310 \\
\hline
\end{tabular}

Table 2: Physical properties of materials.

- The needle was lowered gently to make contact with the paste surface, after which it was released quickly.

- The procedure was repeated every 5 to 10 minutes. The sample paste was considered to be finally set when, upon applying the needle gently to the surface of the test block, the needle made an impression therein, while the attachment failed to do so.

- The time when upon applying the needle gently to the surface of the test block, the needle makes an impression therein, while the attachment fails to do so was also recorded.

- The period elapsing between the time, water was added to the mix and the time, the needle made an impression on the surface of the test block, while the attachment failed to do so was the final setting time.

\section{Results and Discussion}

\section{Physical properties of components}

Laboratory tests on some physical properties of the sourced materials yielded results as presented in Table 2 .

\section{Chemical properties of materials}

Results obtained from XRF analysis of each component are presented in Table 3.

\section{Classification of materials}

Physical properties of coal bottom ash vary widely with origin, but according to the American Coal Ash Association (1997), the specific gravity and density of coal bottom ash range from 2.1-2.7 and 720$1600 \mathrm{~kg} / \mathrm{m}^{3}$ respectively. From Table 2, it is seen that the specific gravity and density of coal bottom ash used fall in these ranges, hence it can be confirmed that the ash used for this research was coal bottom ash.

For bituminous coal ash, the sum total of three major oxides, $\mathrm{SiO}_{2}$, $\mathrm{Al}_{2} \mathrm{O}_{3}$ and $\mathrm{Fe}_{2} \mathrm{O}_{3}$ is greater than $70 \%$ and $\mathrm{CaO}$ is less than $5 \%$ [10]. From Table 3, it is observed that the coal bottom ash falls in this category; hence it is confirmed a bituminous and anthracite coal bottom ash.
According to British geoscientists (BGS) limestone classification based on calcium carbonate content, limestone is said to be impure if it contains less than $85 \% \mathrm{CaCO}_{3}$ and calcite if its $\mathrm{CaCO}_{3}$ content is greater $50 \%$ (Lisa, 2011). Hence the limestone powder used for this research is pure (type LL) and calcite limestone. The above observations are summarized in Table 4.

\section{Effect of limestone variation on setting time}

Both initial and final setting time of blended Portland cement pastes were increased initially with increasing of limestone content at 5 and $10 \%$ constant bottom ash, but decreased with increasing limestone content from 20 to $35 \%$ limestone addition (Figures 4 and 5). This initial

\begin{tabular}{|c|c|c|c|}
\hline Component & Limestone (\%) & Coal Bottom Ash (\%) & OPC (\%) \\
\hline $\mathrm{SiO}_{2}$ & 10.273 & 68.853 & 19.239 \\
\hline $\mathrm{Al}_{2} \mathrm{O}_{3}$ & 3.560 & 24.157 & 5.776 \\
\hline $\mathrm{Fe}_{2} \mathrm{O}_{3}$ & 1.378 & 2.887 & 2.726 \\
\hline $\mathrm{CaO}$ & 46.373 & 0.839 & 60.637 \\
\hline $\mathrm{MgO}$ & 0.447 & 0.237 & 0.781 \\
\hline $\mathrm{SO}_{3}$ & 0.321 & 0.048 & 2.118 \\
\hline $\mathrm{K}_{2} \mathrm{O}$ & 0.550 & 0.683 & 0.955 \\
\hline $\mathrm{Na}_{2} \mathrm{O}$ & 0.039 & 0.146 & 0.167 \\
\hline $\mathrm{P}_{2} \mathrm{O}_{5}$ & 0.126 & 0.124 & 0.171 \\
\hline $\mathrm{Mn}_{2} \mathrm{O}_{3}$ & 0.112 & 0.067 & 0.190 \\
\hline $\mathrm{TiO}_{2}$ & 0.157 & 2.111 & 0.281 \\
\hline $\mathrm{CaCO}_{3}$ & 82.77 & - & - \\
\hline
\end{tabular}

Table 3: Chemical composition of materials.

\begin{tabular}{|c|c|c|}
\hline Material & Description & Type \\
\hline Coal bottom ash & $\begin{array}{c}\text { Bituminous and anthracite, gray in } \\
\text { colour }\end{array}$ & Class F coal ash \\
\hline Pulverized Limestone & Calcite, brown in colour & LL \\
\hline OPC & Pure OPC, ash in colour & IV (Grade 32.5 R) \\
\hline
\end{tabular}

Table 4: Description and classification of materials.

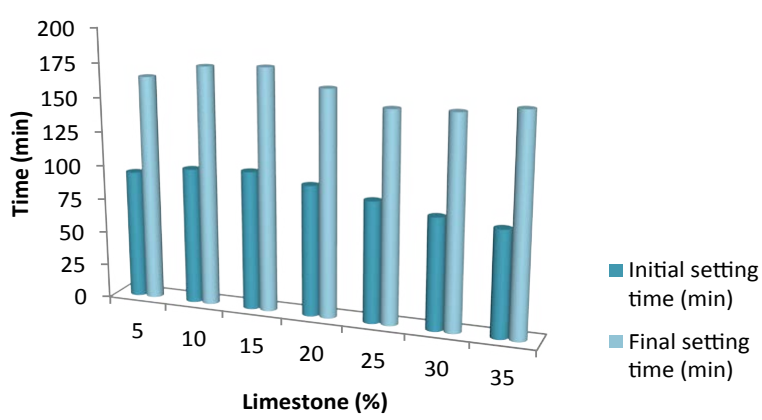

Figure 4: Initial and final setting times at $5 \%$ bottom ash.

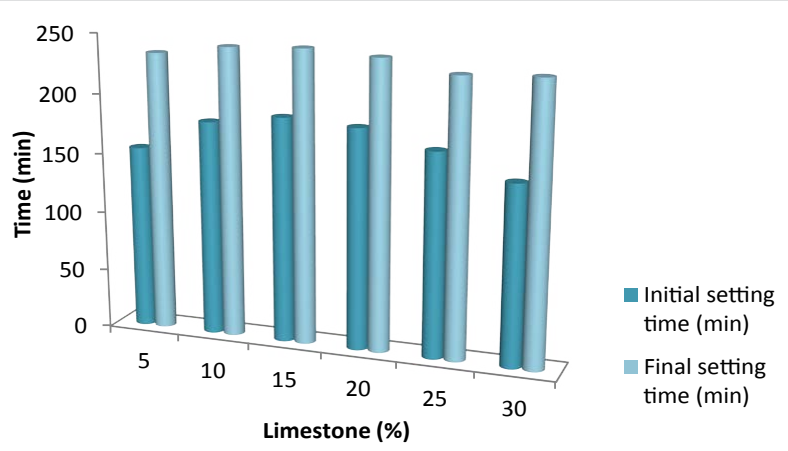

Figure 5: Initial and final setting times at $10 \%$ bottom ash. 
increase in setting time is attributed to the impurities in the pulverized limestone [10]. At $15 \%$ constant bottom ash, the initial setting time increased initially decreased later on with increasing limestone i.e. from $15 \%$ limestone addition (Figure 5).

At $35-40 \%$ total replacement, the final setting time increased significantly, probably due to dilution in the blended cement. It can thus be said that limestone reduces setting time due to its high free lime content. This free lime contributes to the formation of $\mathrm{C}-\mathrm{A}-\mathrm{H}$, which accelerate the setting of cement pastes [10]

\section{Effect of coal bottom ash variation on setting time}

The setting time was longer for bottom ash blends in comparison with pure Portland cement and limestone-rich blended cement. An emphatic delay seems to be caused by the addition of bottom ash (5$15 \%)$. Both initial and final setting times increased with increasing bottom ash content in all cases i.e. at 15-35\% (Figures 6-9).

The period elapsing between initial and final setting time was considerably shorter in bottom ash-rich blended cement than in limestone-rich blended cement. Relative high water demand with addition of bottom ash was observed, a possible contributor to the delay in setting.

Bleeding was also observed at high replacement with bottom ash i.e. at 25,30 and $35 \%$ bottom ash. This can be attributed to the increase in water-cement ratio and the fineness of the bottom ash used. Increase in water-cement ratio and low fineness in turn slow the setting of the blended cement paste. Bottom ash is non-cementitious due to its low free lime content which aid the formation of tri calcium aluminate [9]. Tri calcium aluminate accelerates the setting of cement when mixed water. Bottom ash is also a very silicaceous material, its high silica content retards the setting of cement due to the formation of $\mathrm{SiO}_{2}$ (Lisa, 2011).

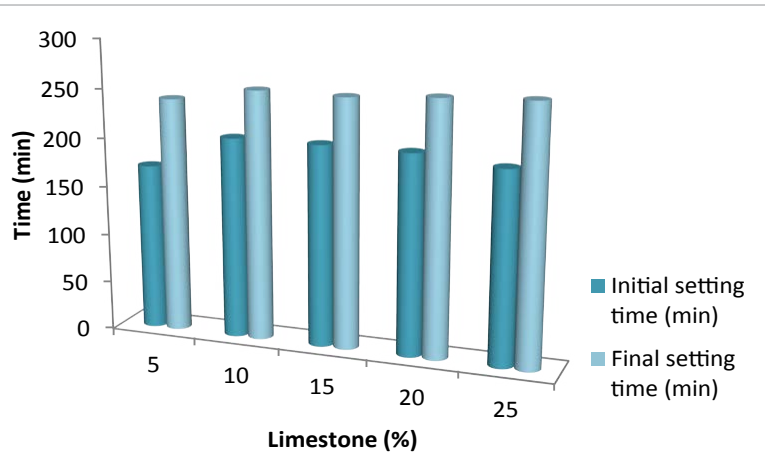

Figure 6: Initial and final setting times at $15 \%$ bottom ash.

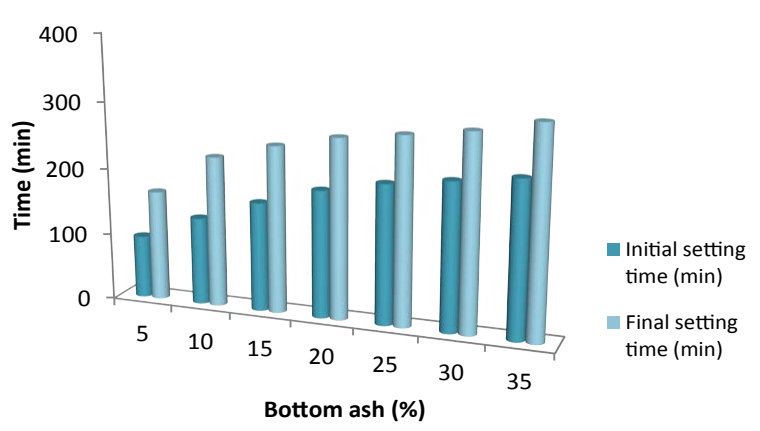

Figure 7: Initial and final setting times at $5 \%$ Limestone.

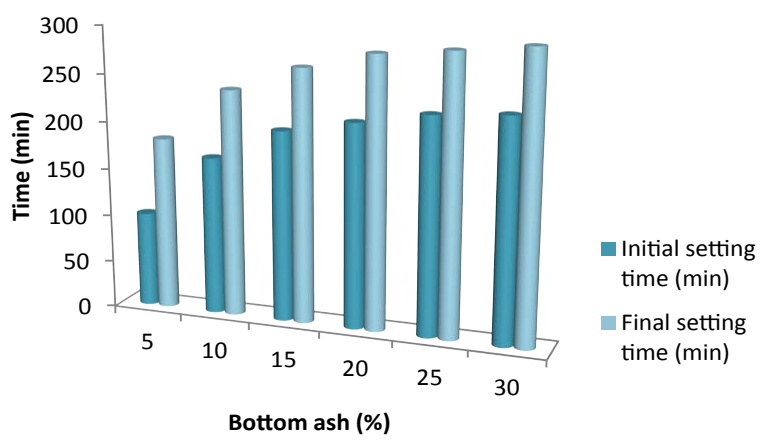

Figure 8: Initial and final setting times at 10\% Limestone.

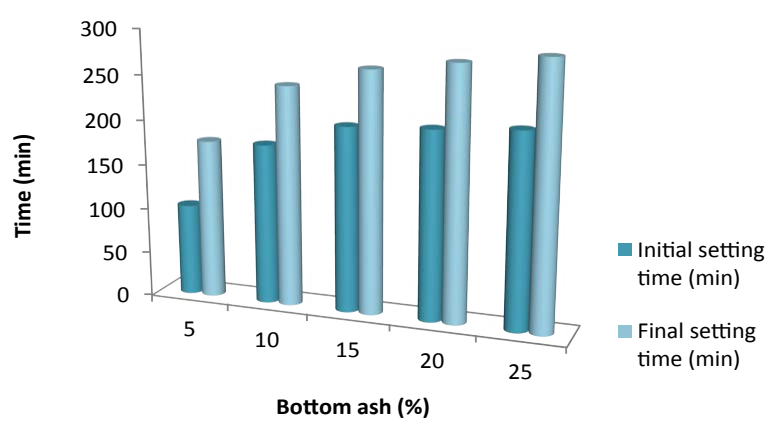

Figure 9: Initial and final setting times at $15 \%$ limestone.

\section{Effect of fineness on setting time}

Long setting times of blends were observed partly due to the fineness of the components used. At the same level of replacement, cement pastes containing small-sized limestone and bottom ash will show lower setting time than those using large-sized limestone and bottom ash. Moreover, the more the level of fine particles in cement or blended cement the higher the specific surface area available for reaction [11]. This invariably increases the rate of hydration and or chemical reaction [12-15].

\section{Conclusion}

This paper investigated the setting behaviour of ternary blends through Vicat penetration test, in accordance with I.S.4031. Results have shown that replacement of OPC with bottom ash retards the setting of cement. Both initial and final setting times increased with increasing bottom ash. A primary reason for this increase in setting time is the increased water demand, low free lime content and high silica content. Both initial and final setting time of blended Portland cement pastes decrease with increase in limestone content, although delay in setting may be observed in some cases at low limestone content as a result of increased water demand caused by the impurities in the limestone. Additional conclusions are drawn as follows:

- Bottom ash is reactive, but far less than Portland cement and limestone.

- Low level of fineness in cement causes decrease in rate of hydration, as a result slows the setting.

- Bleeding can occur in cement paste due to low level of fineness.

- Coal Bottom ash and limestone are good alternative SCMs. 
Citation: Matahula W, Olubajo O (2018) Effects of Limestone and Coal Bottom Ash on Setting Time of Blended Portland Cement (Ternary Cement). J Material Sci Eng 7: 484. doi: 10.4172/2169-0022.1000484

Page 5 of 5

\section{References}

1. Wang K (2004) Improving Concrete Properties Using Environmentally Responsible Mixtures. lowa Online Publications, lowa State University, USA.

2. Shamshad $A$ (2008) Setting of Cement and Microstructure of Hydrated Cement Paste. King Fahd University of Petroleum \& Minerals Dhahran, Saudi Arabia.

3. Bonavetti V, Donza H, Rahhal V, Irassar E (2000) Influence of initial curing on the properties of concrete containing limestone blended cement. Cement and Concrete Research 30: 703-708.

4. Tsivilis S, Chaniotakis E, Kakali G, Batis G (2002) An analysis of the properties of Portland limestone cements and concrete. Cement and Concrete Composites 24: 371-378.

5. Rupnow TD (2012) Evaluation of ternary cementitious combinations (No. FHWA/LA. 11/486). Louisiana Transportation Research Center.

6. Menéndez GVBB, Bonavetti V, Irassar EF (2003) Strength development of ternary blended cement with limestone filler and blast-furnace slag. Cement and Concrete Composites 25: 61-67.

7. Baron J (1987) Technical and economical aspects of the use of limestone filler additions in cement. World cement pp: 100-104.
8. Schlorholtz S (2004) Development of performance properties of ternary mixes: scoping study (No. Final Report).

9. Tony K (2006) Physical and Geotechnical Properties of Coal Ash. Faculty of Civil Engineering, University of Malaysia.

10. Mitchell C (2009) High Purity Limestone Assessment. Saudi Industrial Minerals Workshop, Jedda, Saudi Arabia pp: 3-10.

11. Li HJ, Yang L, Xie YJ (2015) Effect of Fineness on the Properties of Cement Paste. In Key Engineering Materials, Trans Tech Publications 629: 366-370.

12. Hu J, Ge Z, Wang K (2014) Influence of cement fineness and water-to-cement ratio on mortar early-age heat of hydration and set times. Construction and building materials 50: 657-663.

13. Stewart BR (1999) Coal combustion product (CCP) production and use. In Biogeochemistry of Trace Elements in Coal and Coal Combustion Byproducts, Springer, Boston, MA, pp: 1-6.

14. ASTM (2008) Standard test methods for time of setting of hydraulic cement by Vicat needle. C191-08.

15. Gurney L, Bentz DP, Sato T, Weiss J (2012) Using limestone to reduce set retardation 465 in high volume fly ash mixtures: improving constructability for sustainability. In Transportation Research Board 91st Annual Meeting. 